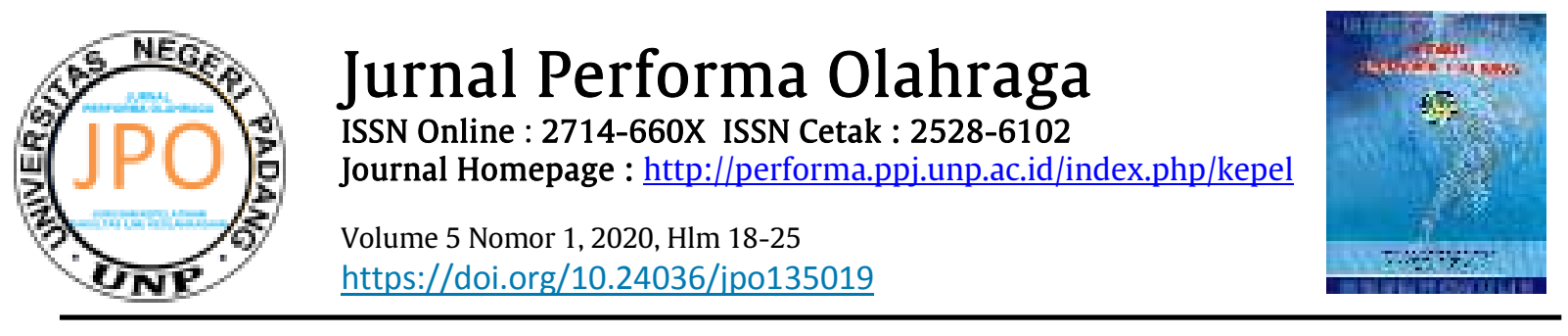

\title{
Pelaksanaan Latihan Beban di Axel Fitness
}

\author{
Jamal Usman ${ }^{1}$, Argantos ${ }^{1}$ \\ ${ }^{1}$ Fakultas Ilmu Keolahragaan, Universitas Negeri Padang, Indonesia \\ Universitas Negeri Padang, Indonesia.
}

\section{Informasi Artikel}

Diterima 25-05-2020

Direvisi 01-06-2020

Dipublikasikan 08-06-2020

\section{Keyword:}

Fitness

Weight Training

Personal Trainer

Member

\begin{abstract}
The problem in this research is that the weight training method in Axel fitness in Guguak District, Kabupaten 50 Kota is still a lot wrong. The purpose of this study was to determine the method of weight training for members who use the services of personal trainers, the quality of personal trainers and infrastructure facilities in weight training in Axelfitness Guguak District, District 50 City. The research method is qualitative research. Data collection methods used are observation, interviews and documentation. The data analysis technique used is a qualitative analysis technique that includes three concurrent activities namely data reduction, data presentation and drawing conclusions. The results of research and discussion are: Method of weight training for members who use personal services The trainer is in accordance with the weight training method, but there are still some techniques that must be improved such as breathing and the principle of training. Furthermore, the quality of personal trainers in weight training is quite good, it can be seen that personal trainers have achievements in the bodybuilding branch, but personal trainers do not have a license and do not equip members with weight training programs. and Sarana and infrastructure in weight training at Axel fitness is quite complete. Existing facilities include training equipment for pivot machines, CAM machines and free weights and infrastructures including: Weight training room, parking area, locker room, lockers or goods storage area
\end{abstract}

(c) 2020 The Authors. Published by Universitas Negeri Padang. This is an open access article under the CC BY-NC-SA license https://creativecommons.org/licenses/by-nc-sa/4.0

\section{Penulis Korespondensi:}

Jamal Usman

Universitas Negeri padang

Email: jamalusman300@gmail.com

\section{PENDAHULUAN}

Olahraga adalah suatu kegiatan aktifitas fisik yang bisa dilakukan diluar maupun didalam ruangan.Semua orang mengetahui bahwa olahraga sangat penting bagi tubuh, karena mendapatkan tubuh yang sehat dan bugar. Pada saat sekarang ini olahraga tidak hanya mencari kebugaran saja akan tetapi sudah menjadi tren atau gaya hidup disemua kalangan. Sebagian besar masyarakat Indonesia sudah menyadari bahwa pemiliharaan kesehatan sangat mutlak selama manusia masih menghendaki hidup sehat jasmani dan rohani.Kebugaran jasmani merupakan aspek fisik dari kesegaran yang menyeluruh, yang memberikan kesanggupan kepada seseorang untuk menjalankan hidup produktif dan dapat menyesuaikan diri pada tiap pembebanan fisik yang layak.

Menurut (Hasibuan, 2019) mengatakan bahwa "Kebugaran jasmani adalah elemen yang diperlukan untuk semua kegiatan kita”.Secara definisi kebugaran jasmani adalah sesanggupan 
tubuh dalam penyesuayan terhadap pembebanan fisik tanpa menggalami kelelahan yang berarti, yang menjadi penekanan yaitu kesanggupan tubuh secara fisiologis menyesuaikan terhadap beban efisien.Menurut (Yisuf, 2018) mengatakan "Kebugaran jamani yang berhubungan dengan kesehatan dan kelompok yang berhubungan dengan unsur keterampilan dan performance".'Mengigat banyaknya manfaat positif yang diperoleh jika kesegaran jasmani baik, maka kesadaran masyarakat untuk melakukan olahraga kebugaran jasmani makin menigkat. Untuk mendapatkan fisik yang prima, masyarakat banyak memilih menjadi anggota di pusat kebugaran atau fitness. Dalam latihan beban member harus faham dengan pelaksanaan latihan beban diantaranya metode latihan beban dan prinsip pembebanan.(Suryono dalam Halaman Olahraga Nusantara. 2018) mengatakan "Bahwa fitness center atau dalam bahasa Indonesianya pusat kebugaran biasa bisa dikenal dengan istilah " $g y m$ " adalah suatu tempat untuk menampung berbagai macam alat-alat latihan kesehatan untuk mengadakan latihan fisik". Sedangkan menurut (Utomo dalam Halaman olahraga nusantara. 2018) menyatakan bahwa "Fitness center merupakan suatu layanan di bidang kesehatan yang membantu masyarakat umum meningkatkan kesehatan fisik, dimana tidak hanya masyarakat menjadi lebih sehat tetapi juga juga termotivasi memiliki diri yang semangat".Dreger dalam (Sucipto. 2016) menjelaskan"Latihan beban (weght training)adalah aktifitas fisik yang dilakukan secara sistematis dengan mengunakan beban sebagai alat untuk meningkatkan kekuatan otot untuk mencapai tujuan seperti memperbaiki kondisi fisik member, mencegah terjadinya cidera atau tujuan kesehatan".

Capen dalam Bafirman ( 2010) mengatakan "Latihan beban adalah paling efektif untuk fisik yang terlatih untuk perkembangan lebih lanjut dari otot rangka. Beberapa syarat dan prinsip yang penting diperhatikan dalam latihan beban sebagimana yang dikemukakan oleh Adisasmita dalam Bafirman (2010) adalahLatihan beban harus didahulukan dengan pemanasan yang menyeluruh, kemudian Prinsip beban harus diterapkan, Setiap mengangkat, mendorong atau menarik beban harus dilaksanakan dengan benar, ulangan angkat beban sedikit demi sedikit kemudian tambahkan beban maksimal menghasilkan adaptasi terhadap kekuatan, sedangkan ulangan banyak denga beban ringan akan menghasilkan perkembangan daya tahan otot, selanjutnya setiap bentuk latihan harus dilakukan dengan ruang gerak seluas-luasnya yaitu sampai pada batas sendi, sehingaotot-otot terasa agak tertarik.Latihan beban dilakukan tiga kali semimggu dan diselingi dengan satu hari istirahat, yang penting dalam latihan beban yaitu harus diawasi oleh pelatih yang mengerti betul tentang latihan beban. Metode latihan beban di Axel Fitness Kecamatan Guguak, Kabupaten 50 Kota sudah sesuai dengan pelaksanaan latihan beban akan tetapi masih ada beberapa teknik yang salah dalam pelaksanaanya, diantaranya pernafasan dalam latihan dan menerapkan prinsip latihan beban.

Menurut (Wayment dan McDonald dalam Madani dan Susanto2019) "personal trainer membantu member dalam menetapkan tujuan yang sesuai merancang (terutama penting selama inisiasi program latihan), merancang protokol latihan yang membentu mencapai tujuan latihan itu, dan mencatat peningkatan dan kemajuan latihan".Menurut (Awaluddin dan Nurmasyitah. 2018).mengatakan "Dalam pelaksanaan program latihan harus memiliki sasaran dari apa yang ingin dilatih, aktifitas fisik yang diberikan tidak biasa diberikan secara umum terus menerus, untuk itu pelatih yang baik harus memahami ilmu kepelatihan". Dalam dunia kebugaran peran seorang personal training atau instruktur sangat penting dalam ketercapayan tujuan latihan.Tugas instruktur atau personal trainer adalah memberikan pelatihan dan bimbingan pada member serta membuat suatu program latihan.Sedangkan Menurut (Akhmad. 2015) "Seorang pelatih harus mampu merancang program latihan yang bermutu dengan memandukan perkembangan iptek ke dalam penyusunan program latihanya”. Disamping itu juga, penting kiranya mengetahui struktur dan tipe otot sebagai dasar pemilihan cabang olahraga.Personal trainer di Axel fitness dalam pelaksanaan latihan beban yang di jalankan member tidak berjalan dengan semestinya, dalam artian personal trainer jarang mendampinggi member dalam latihan beban dan personal trainr juga tidak membekali member dengan program latihan.

Menurut(Anandita. 2013) "Sarana adalah segala sesuatu yang dapat dipakai sebagai alat yang dicapai untuk mencapai maksut dan tujuan, sedangkan prasarana sering disebut infrastruktur".Sarana olahraga adalah sumber daya pendukung yang terdiri dari segala bentuk dan jenis peralatan serta perlengkapan yang digunakan dalam kegiatan olahraga.Prasarana olahraga adalah sumber daya pendukung yang terdiri dari tempat olahraga yang terdiri dari bangunan 
diatasnya dan batas fisik yang berstatus jelas dan memenuhi persyaratan yang ditetapkan untuk pelaksanaan latihan.Dilihat dari prasarana latihan beban di Axel fitness, peneliti melihat sarana yang digunakan dalam latihan beban di Axelfitness terdapat berbagai jenis alat latihan beban diantaranya mesin pivot4 unit, mesin Cam5 unit, Grip7 unit, barbell 50 lempeng dengan berat 2,3 $\mathrm{kg}, 5 \mathrm{~kg}, 10 \mathrm{~kg}, 20 \mathrm{~kg}$, dumbbell 10 pasang dengan berat berfariasi diantaranya, 2,5 kg, $5 \mathrm{~kg}, 10 \mathrm{~kg}$, $12,5 \mathrm{~kg}, 15 \mathrm{~kg}, 17 \mathrm{~kg}, 20 \mathrm{~kg}, 25 \mathrm{~kg}, 30 \mathrm{~kg}$ dan $35 \mathrm{~kg}$. kemudian prasarana yang diguakan dalam latihan beban diantaranya tempat parkir cukup luas, tempat latihan dengan luas 15 X 6 meter, locker atau tempat penyimpanan barang satu unit, ruang ganti, cermin di dinding dan lantai beralaskan karpet.

Menurut (Santosa dalam Hanafi 2010) mengatakan "Hasil adaptasi suatu latihan merupakan adaptasi fisiologis yang merupakan perubahan perilaku fungsional suatu organ atau system dalam tubuh yang bersifat nenetap oleh pengaruh dalam kegiatan olahraga, teratur dan kelanjutan dalam waktu yang lama, yang merupakan pertanda meningkatnya kemampuan fungsional serta efisiensinya".

\section{METODE}

Dalam hal ini menggunakan penelitian kualitatif menggunakan metode deskriptif dengan pengamatan terhadap fenomena- fenomena atau gejala-gejala sosial yang alamiah (nature). Moleong, (2012) mengatakan "Penelitian fenomenologi berorientasi untuk memahami arti peristiwadan kaitan-kaitannyaterhadap orang-orang yang berada dalam situasi tertentu".

Penelitian kualitatif adalah penelitian yang menghasilkan data deskriptif berupa kata-kata tertulis atau lisan dari orang-orang atau perilaku yang diamati Moleong, (2012). Dengan demikian penelitian ini menggunakan metode deskriptif dan teknik analisis kualitatif. Teknik pengumpulan data yang digunakan adalah observasi, wawancara dan studi dokumentasi.

Teknik pengumpulan data merupakan langkah yang paling utama dalam penelitian, karena tujuan utama dari penelitian adalah mendapatkan data. Dalam penelitian ini pengumpulan data dilaksanakan dengan cara langsung terjun kelapangan untuk mendapatkan sejumlah data yang dibutuhkan berkenaan denganpelaksanaan latihan beban diAxelfitness Kecamatan Guguak, Kabupaten 50 kota

Menurut Ngalim Purwanto (1985) dalam Basrowi \& Suwandi, (2008) observasi adalah metode atau cara-cara menganalisis dan mengadakan pencatatan secara sistematis mengenai tingkah laku dengan melihat atau mengamati individu atau kelompok secara langsung.Metode ini digunakan untuk melihat dan mengamati secara langsung keadaan dilapangan agar peneliti memperoleh gambaran yang lebih luas tentang permasalahan yang diteliti.Menurut Moleong, (2012) ada beberapa pokok persoalan yang dibahas disini diantaranya,alasan pemanfaatan pengamatan, Macam-macam pengamatan dan derajat peranan pengamat dan apa yang diamati, Pengamatan dan pencatatan data selanjutnya pengamat yang diamati kemudian kelemahan pengamatan.

Objek yang diamati adalah Pelaksanaan latihan beban diAxelfitness centerKecamatan Guguak, Kabupaten 50 kota.Melalui pengamatan secara langsung maka dapat melihat dan mengamati secara langsung tentangmetode latihan beban dan kualitaspersonal trainer dalam pelaksanaan latihan beban di Axelfitness Kecamatan Guguak,Kabupaten 50 Kota.Observasi dilakukan dengan menggunakan pedoman observasi. Beberapa informasi yang diperoleh dari hasil observasi adalah ruang (tempat), pelaku, kegiatan, objek, perbuatan, kejadian atau peristiwa, waktu, dan perasaan. Alasan melakukan observasi adalah untuk menyajikan gambaran realistik perilaku atau kejadian, untuk menjawab pertanyaan, untuk membantu mengerti perilaku manusia, dan untuk evaluasi yaitu melakukan pengukuran terhadap aspek tertentu melakukan umpan balik terhadap pengukuran tersebut, bukan hanya mencatat reaksi tersebut, tetapi juga menilai reaksi tersebut apakah sangat kurang, atau tidak sesuai dengan apa yang dikehendaki. Menurut Adler dan Adler dalam Hasyim Hasanah ( 2016 ) "Menyebutkan bahwa observasi merupakan salah satu dasar fundamental dari semua metode pengumpulan data dalam penelitian kualitatif, khususnya menyangkut ilmu-ilmu social dan perilaku manusia".

MenurutMoleong, (2012) mengemukakan bahwa "Wawancara adalah percakapan dengan maksud tertentu. Percakapan itu dilakukan oleh dua pihak, yaitu pewawancara yang mengajukan 
pertanyaan dan terwawancara yang memberikan jawaban atas pertanyaan itu".Sedangkan menurut Basrowi dan suwandi, (2008) "Wawancara adalah percakapan dengan maksut tertentu oleh dua pihak, yaitu pewawancara (interviewer) sebagai pengaju/pemberi pertanyaan dan yang diwawancarai (interviewee)sebagai pemberi jawaban dari pertanyaan itu.Dalam hal ini pewawancara hanya membacakan pertanyaan yang telah disusun kemudian mencatat menjawap responden secara tepat. Dalam proses pengumpulan data, peneliti hanya menyusun pertanyaanpertanyaan yang akan dijawap oleh member dan personal trainer.

Basrowi \& Suwandi (2008) "Dalam hal ini peneliti menggunakan dokumentasi foto-foto kegiatan dan berbagai informasi yang dapat dipergunakan sebagai pendukung hasil penelitian".Dokumentasi akan di ambil darimember dan personal trainerdiAxelfitnessKecamatan Guguak, Kabupaten 50 Kota.Adapun prosedur yang dipakai dalam penelitian ini berdasarkan teori Miles dan Huberman dalam Basrowi dan Suwandi, (2008) yang terdiri beberapa tahapdiantaranyareduksi data berarti menajamkan,menggolongkan, mengarahkan, membuang yang tidak perlu dan mengorganisasi data sehinngga kesimpulan akhir dapat diambil. Dalam teknik reduksi data ini peniliti memilih hal-hal pokok dan penting sehingga data yang telah di reduksi akan memberikan gambaran yang jelas. Penyajian data adalah sekumpulan informasi tersusun yang memberi kemungkinan untuk menarik kesimpulan dan pengambilan tindakan. Bentuk penyajiannya antara lain berupa teks naratif, matriks, grafik, jaringan dan bagan. Penyajian data dalam penelitian ini dilakukan dalam bentuk uraian singkat dengan teks yang bersifat naratif, menarik kesimpulan yaitu data yang diolah kemudian menghasilkan kata-kata dan kalimat yang dapat dimengerti. sehingga nantinya akan diperoleh kesimpulan dari data yang telah diolah tersebut.

Berdasarkan hasil opservasi, wawancara dan studi dokumentasi yang peneliti lakukan berkaitan dengan Metode latihan beban, kualitas personal trainer dalam latihan beban dan sarana dan prasarana dalam latihan beban, peneliti memperoleh informasi sebagai berikut :Metode latihan beban diAxel fitness Kecamatan Guguak Kabupaten 50 Kota, pada saat melakukan wawancara dengan member yang memakai jasa personal trainer pada tangal 05 September 2019. Dalam latihan mereka di ajarkan tentang metode latihan beban oleh personal trainerdiantaranya, untuk otot dada, bench press, detline press, incline press. Untuk otot punggung saya memakai alat Pull Down.Untuk otot deltoid alat yang saya pakai yaitu smith machine dan dumbbell.dan otot paha leg press dan squat'.selanjutnyapersonal trainer mengatakan, Saya mengajarkan semua bentuk latihan dan metode latihan beban kepada member dari pemanasan sampai latihan inti, kualitas personaltrainer di Axelfitness Kecamatan Guguak, Kabupaten 50 Kota, Personal trainer di AxelFitness Kecamatan Guguak, Kabupaten 50 Kota merupakan masyarakat asli Talang Maur, Kabupaten 50 Kota. Beliau mulai menjadi personal trainer sejak tahun 2018. Dari hasil wawancara dengan personal trainerAxel Fitness pada tanggal 05 September 2019 di Axel Fitness Kecamatan Guguak, Kabupaten 50 Kota dan peneliti mendapatkan informasi sebagai berikut: personal trainer mempunyai prestasi di tingkat Provinsi dan Nasional di cabang binaraga, personal trainer tidak mempunyai lisensi dan personal trainer tidak membekali member dengan program latihan beban, selanjutnya sarana dan Prasarana latihan beban di Axel Fitness Kecamatan Guguak, Kabupaten 50 Kota, dilihat dari prasarana latihan, peneliti melihat sarana yang digunakan untuk latihan beban cukup baik, peneliti melihat sarana yang digunakan dalam latihan terdapat berbagai jenis alat latihan beban diantaranya mesin pivot 4 unit, mesin Cam 5 unit, Grip 7 unit, barbell 50 lempeng dengan berat $2,3 \mathrm{~kg}, 5 \mathrm{~kg}, 10 \mathrm{~kg}, 20 \mathrm{~kg}$, dumbbell 10 pasang dengan berat berfariasi diantaranya, 2,5 kg, $5 \mathrm{~kg}, 10 \mathrm{~kg}, 12,5 \mathrm{~kg}, 15 \mathrm{~kg}, 17 \mathrm{~kg}, 20 \mathrm{~kg}, 25 \mathrm{~kg}, 30 \mathrm{~kg}$ dan $35 \mathrm{~kg}$.

Prasarana yang diguakan dalam latihan beban diantaranya tempat parkir cukup luas, tempat latihan dengan luas 15 X 6 meter, locker atau tempat penyimpanan barang satu unit, ruang ganti, cermin di dinding dan lantai beralaskan karpet.

\section{HASIL DAN PEMBAHASAN}

\section{Hasil Penelitian}

Hasil penelitian berdasarkan deskripsi hasil temuan mengenai pelaksanaan latihan beban di Axelfitness Kecamatan Guguak,Kabupaten 50 Kota akan dibahas sebagai berikut: 
Metode Latihan beban di Axel fitness Kecamatan Guguak, Kabupaten 50Kota.

Pelaksanaan latihan beban yang dijalankan memberyang memakai jasa personal trainer sudah sesuai dengan metode latihan beban. Beberapa syarat dan prinsip yang penting diperhatikan dalam latihan beban sebagaimana yang dikemukakan oleh Adi Sasmita dalam Bafirman, (2010:53) adalah:

1. Latihan beban harus didahulukan dengan pemanasan yang menyeluruh.

2. Prinsip beban harus diterapkan.

3. Setiap mengangkat, mendorong atau menarik beban harus dilaksanakan dengan benar.

4. Ulangan angkat beban sedikit demi sedikit, dengan beban maksimal menghasilkan adaptasi terhadap kekuatan, sedangkan ulangan banyak

Dengan beban ringan akan menghasilkan perkembangan dayatahan otot.

5.Setiap bentuk latihan harus dilakukan dengan ruang gerak seluas- luasnya, yaitu sampai pada batas sendi,sehinga otot-otot terasa agak tertarik.

6. Latihan beban dilakukan tiga kali semimggu dan diselingi dengan satu hari istirahat.

7. Latihan beban harus diawasi oleh pelatih yang mengerti betul tentang latihan beban.

Menurut Irawadi, (2014:38-43) "prinsip pembebanan diartikan sebagai ketentuanketentuan dalam suatu latihan. Dalam menyusun program atau kegiatan pada setiap kali latihan harus diawali dengan tujuan, takaran, bentuk, dan cara-cara pelaksanaan”, antara lain. 1)Tujuan Latihan 2) Takaran latihan 3) Bentuk latihan 4) Intensitas Latihan 5) Waktu Pembebanan ( durasi )

Dari hasil wawancara dan pengamatan yang peneliti peroleh ,metode latihan beban yang dijalankan member yang memakai jasa personal trainer sudah sesuai dengan metode latihan beban, akan tetapi dalam menentukan beban awal dalam latihan beban belum sesuai dengan metode latihan beban yang seharusnya 50\%-60\% dari berat badan selanjutnya dalam teknik pernafasan dalam latihan, dalam latihan beban member masih salah, ini dapat dilihat ketika melakukan wawancara dan mempraktekkan langsung, member menggungkapkan dalam pernafasan saya tidak menentu. Maka dariitu member tidak mendapatkan hasil yang maksimal latihan beban.

Kualitas personal trainer dalam latihan beban di Axel fitness Kecamatan Guguak, Kabupaten 50 Kota.

Personal ntrainer yaitu mereka dapat memberikan pengetahuan, pembelajaran teknik yang benar, dan fungsi dari latihan yang dilakukan, yang paling penting seorang personal trainer harus memiliki pengalaman yang baik dalam bidangnya.Seorang personal trainer juga harus mengajarkan member metode latihan beban dan harus membekali member dengan program latihan beban. Menurut Syafruddin, (2013:5) mengatakan" Seorang pelatih harus memahami metode latihanya, bentuk-bentuk atau materi latihanya serta pemahaman tentang prinsipprinsip latihan".

Dari pendapat para ahli diatas dapat disimpulkan, kualitas personal trainer dalam latihan beban di Axel fitness Kecamatan Guguak, Kabupaten 50 Kota cukup baik atau sudah berpengalaman dalam menjadi personal trainer, ini dibuktikan dengan prestasi dicabang binaraga yang telah menjuarai ditingkat provinsi dan nasional. Tapi sayangnya, personal trainer tidak memiliki lisensi juga tidak membekali member dengan program latihan beban.

\section{Sarana dan prasarana dalam pelaksanaan latihan beban diAxel Fitness kecamatan Guguak, Kabupaten 50 Kota.}

Sarana dan prasarana tempat pelaksanaan latihan merupakan elemen yang sangat penting dalam proses latihan beban. Sarana dalam latihan beban menurut Thomas $R$ dalam kardiawan kusuma, (2014:10) mengatakan, peralatan latihan beban terdiri dari dua macam yaitu mesin pivot (PM) dan mesin CAM. Dari hasil pengamatan yang peneliti peroleh, Dilihat dari prasarana latihan, peneliti melihat sarana yang digunakan untuk latihan beban cukup baik, peneliti melihat sarana yang digunakan dalam latihan beban di Axel fitness terdapat berbagai jenis alat latihan beban diantaranya mesin pivot4 unit, mesin Cam5 unit, Grip7 unit, barbell 50 lempeng dengan berat $2,3 \mathrm{~kg}, 5 \mathrm{~kg}, 10 \mathrm{~kg}, 20 \mathrm{~kg}$, dumbbell 10 pasang dengan berat berfariasi diantaranya, 2,5 kg, $5 \mathrm{~kg}, 10 \mathrm{~kg}, 12,5 \mathrm{~kg}, 15 \mathrm{~kg}, 17 \mathrm{~kg}, 20 \mathrm{~kg}, 25 \mathrm{~kg}, 30 \mathrm{~kg}$ dan $35 \mathrm{~kg}$. 
Prasarana yang digunakan dalam latihan beban diantaranya tempat parker cukup luas,tempat latihan dengan luas15X 6 meter, locker atau tempat penyimpanan barang satu unit, ruang ganti,cermin didinding dan lantai beralaskan karpet.

\section{PEMBAHASAN}

Hasil penelitian berdasarkan deskripsi hasil temuan mengenai pelaksanaan latihan beban di Axel fitness Kecamatan Guguak, Kabupaten 50 Kota akan dibahas sebagai berikut,Metode Latihan beban di Axelfitness Kecamatan Guguak, Kabupaten 50 Kota, pelaksanaan latihan beban yang dijalankan member yang memakai jasa personal trainer sudah sesui dengan metode latihan beban. Beberapa syarat dan prinsip yang penting diperhatikan dalam latihan beban sebagimana yang dikemukakan oleh Adisasmita dalam Bafirman, (2010:53) adalah: Pertama latihan beban harus didahulukan dengan pemanasan yang menyeluruh, selanjutnya prinsip beban harus diterapkan, kemudian setiap mengangkat, mendorong atau menarik beban harus dilaksanakan dengan benar,ulangan angkat beban sedikit demi sedikit, dengan beban maksimal menghasilkan adaptasi terhadap kekuatan, sedangkan ulangan banyak denga beban ringan akan menghasilkan perkembangan daya tahan otot, setiap bentuk latihan harus dilakukan dengan ruang gerak seluasluasnya, yaitu sampai pada batas sendi, sehinga otot-otot terasa agak tertarik, latihan beban dilakukan tiga kali semimggu dan diselingi dengan satu hari istirahat, dan dalam latihan beban harus diawasi oleh pelatih yang mengerti betul tentang latihan beban.

Dari hasil wawancara dan pengamatan yang peneliti peroleh, metode latihan beban yang dijalankan member yang memakai jasa personal trainer sudah sesui dengan metode latihan beban, akantetapi dalam menentukan beban awal dalam latihan beban belum sesuai dengan metode latihan beban yang seharusnya 50\%-60\% dari berat badan selanjutnya dalam teknik pernafasan dalam latihan, dalam latihan beban member masih salah, ini dapat dilihat ketika melakukan wawancara dan mempraktekkan langsung, member menggungkapkan dalam pernafasan saya tidak menentu. Maka dari itu member tidak mendapatkan hasil yang maksimal latihan beban. Selanjutnyakualitas personal trainerdalam latihan beban di Axelfitness Kecamatan Guguak, Kabupaten 50 Kota,Personal traineryaitu mereka dapat memberikan pengetahuan, pembelajaran teknik yang benar, dan fungsi dari latihan yang dilakukan, yang paling penting seorang personal trainerharus memiliki pengalaman yang baik dalam bidangnya. Seorang personal trainer juga harus mengajarkan member metode latihan beban dan harus menbekali member dengan program latihan beban. Menurut Febriana dalam Erik Soebari dan Made Pramoto (2016) "Personal trainer adalah orang yang membantu pelanggan dalam menjalankan latihan kebugaran secara baik dan benar, membuat program untuk setiap member, memastikan para member melakukan latihan yang benar dan sesuai dengan ketentuan program latihan.Dari pendapat di atas dapat disimpulkan, kualitas personal trainer dalam latihan beban di Axelfitness Kecamatan Guguak, Kabupaten 50 Kota cukup baik atau sudah berpengalan dalam menjadi personal trainer, ini dibuktikan dengan prestasi di cabang binaraga yang telah menjuarai di tingkat provinsi dan nasional. Tapi sayangnya, personal trainer tidak memiliki lisensi juga tidak membekali member dengan program latihan beban.Kemudian sarana dan prasarana dalam pelaksanaan latihan beban di Axel Fitness Kecamatan Guguak, Kabupaten 50 Kota,Menurut (Anandita. 2015) "Sarana adalah segala sesuatu yang dapat dipakai sebagai alat yang dicapai untuk mencapai maksut dan tujuan, sedangkan prasarana sering disebut infrastruktur".Dari hasil pengamatan yang peneliti peroleh, Dilihat dari prasarana latihan, peneliti melihat sarana yang digunakan untuk latihan beban cukup baik, peneliti melihat sarana yang digunakan dalam latihan beban di Axelfitness terdapat berbagai jenis alat latihan beban diantaranya mesin pivot 4 unit, mesin Cam 5 unit, Grip 7 unit, barbell 50 lempeng dengan berat 2,3 kg, $5 \mathrm{~kg}, 10 \mathrm{~kg}, 20 \mathrm{~kg}$, dumbbell 10 pasang dengan berat berfariasi diantaranya, 2,5 kg, $5 \mathrm{~kg}, 10 \mathrm{~kg}, 12,5 \mathrm{~kg}, 15 \mathrm{~kg}, 17 \mathrm{~kg}, 20 \mathrm{~kg}, 25 \mathrm{~kg}, 30 \mathrm{~kg}$ dan $35 \mathrm{~kg}$ dan Prasarana yang diguakan dalam latihan beban diantaranya tempat parkir cukup luas, tempat latihan dengan luas 15 X 6 meter, locker atau tempat penyimpanan barang satu unit, ruang ganti, cermin di dinding dan lantai beralaskan karpet. 


\section{KESIMPULAN}

Berdasarkan uraian dari hasil penelitian dan pembahasan yang telah dilakukan, maka peneliti dapat menarik kesimpulan,Metode latihan beban yang dijalankan member yang memakai jasa personal trainer sudah sesuai dengan latihan beban yang peneliti ajukan. Ketika peneliti melakukan wawancara dan mempresentasikan langsung dengan mengunakan alat kepada member, antara jawaban dan yang di presentasikan dengan menggunakan alat masih ada yang salah dalam pelaksanaanya, diantaranya dalam menentukan beban awal dalam latihan belum sesuai dengan metode latihan beban yang seharusnya yaitu 50\%-60\% dari berat badan selanjutnya dalam teknik pernafasan dalam latihan masih salah. ini dapat dilihat ketika melakukan wawancara dan mempraktekkan langsung, member menggungkapkan dalam pernafasan saya tidak menentu dan yang peneliti lihat juga sama yang diungkapkan member. Kemudian hasil yang didapat peneliti dalam mengkajikualitas personal trainer dalam pelaksanaan latihan beban yang dilakukan member di Axelfitness Kecamatan Guguak, Kabupaten 50 Kota, secara umum cukup baik, ini bisa dilihat personal trainer memiliki prestasi di cabang binaraga di tingkat Provinsi dan nasional. Sayangnya personal trainer tidak memiliki lisensi dan tidak membekali member dengan program latihan beban. Selanjutnya peneliti melihatsarana dan prasarana dalam latihan beban di Axel fitness Kecamatan Guguak, Kabupaten 50 Kota cukup lengkap. Sarana yang ada diantaranya alat latihan baban mesin pivot, mesin $C A M$ dan beban bebas, alat mesin povot berjumlah 4 unit, alat mesin Cam 5 Unit, dumbell 10 pasang dengan berat bervariasi, barbell 50 lempeng dengan berat bervariasi dan grip 7 unit dan prasarana diantaranya: Ruangan latihan beban luas 15X6 M, tempat parkir, Ruang ganti satu ruangan, Locker atau tempat menyimpat barang satu unit.

\section{DAFTAR PUSTAKA}

Asteryna Anandita, Moch, Saleh Soeaidy, Minto Hadi (2013). Pelaksanaan Pembangunan Sarana Prasarana Lingkungan Sebagai Wujut Program Pemberdayaan Masyarakat Di Kelurahan Diyono Kota Malang.Jurnal Administrasi Publik(JPA).Vol. 1, No. 5 hal.853-861.

Awaluddin dan Nurmasyitah.(2018). Pengaruh Latihan Beban Terhadap Kecepatan Lemparan Pitching Ball Pada Atlet Softball Aceh 2015.Jurnal Pesona Dasar:Vol. 6.1, April 2018, hal.3540.

Bafirman,2010. Pembentukan Kondisi Fisik. Malang : Wineka Media

Basrowi \& Suwandi. 2008. Memahami Kualitatif. Jakarta : Rineka Cipta

Eko Sucipto dan Widiayanto. (2016). Pengaruh Latihan Beban Dan Kekuatan Otot Terhadap Hypertrophy Otot Dan Ketebalan Lemak. Jurnal Keolahragaan. Vol. 4, No. 1, April 2016, hal. 111-121.

Erik Soebari dan Made Pramono.(2016). Kopentensi Dan Orientasi Pelayanan Personal Trainer Atlas Sports Club Surabaya.Jurnal Kesehatan Olahraga, Vol. 06 No. 2 Oktober hal. 145-160.

Davit Yisuf (2018). Evaluasi Kebugaran Jasmani Melalui Harvard test Pada Mahasiswa PJKR Tahun 2016/2017 IKIP BUDI UTOMO. Jurnal Pendidikan. Jasmani, Olahraga dan kesehatan, Vol.1,No. 2, Mei 2018.

Hasyim Hasanah. ( 2016 ). Teknik-Teknik Observasi. Jurnal at-Taqaddum, Vol. 8, No. 1, Juli 2018.

Ichasan Madani Hasibuan dan Indra Himawan Susanto.2019. Analisis Tingkat Daya Tahan Kardiovaskuler Personal Trainer PR60 Workout Center Surabaya.Jurnal Kesehatan Olahraga, Vol 07, Edisi Juli 2019 hal 502-509.

Imran Akhmat. (2015). Efektifitas Berbeban Terhadap Fungsi Kerja Otot.Jurnal Pedagogik. Vol 1, No. 2, Juli-Desember 2015,hal.80-102. 
Reverorlando.(2018). Halaman Olahraga Nusantara.Jurnal Ilmu Keolahragaan, Vol.1 No.1 Januari 2018.

Moleong, 2012. Metodologi Penelitian Kualitatif. Bandung ; PT Remaja.

Suriah Hanafi. (2010). EfektivitasLatihan Beban Dan Latihan Pliometrik Dalam Meningkatkan Kekuatan Otot Tungkai Dan Kecepatan Reaksi. Jurnal ILARA. Vol. 1, No.2, Desember 2010, hal. 1-9 